\title{
Physicochemical and Functional Properties of Brown Rice (Oryza sativa) and Wheat (Triticum aestivum) Flour and Quality of Composite Biscuit Made Thereof
}

\author{
M. Z. Islam ${ }^{1 *}$, M. L. J. Taneya ${ }^{2}$, M. Shams-Ud-Din ${ }^{2}$, M. Syduzzaman ${ }^{3}$ and M. M. Hoque ${ }^{1}$ \\ ${ }^{I}$ Dept. of Food Engineering and Tea Technology, ShahJalal University of Science and Technology, \\ Sylhet, Bangladesh; ${ }^{2}$ Dept. of Food Technology and Rural Industries, Bangladesh Agricultural \\ University, Mymensingh, Bangladesh; ${ }^{3}$ Dept. of Nutrition and Food Technology, Jessore Science and \\ Technology University, Jessore, Bangladesh \\ *Corresponding author and Email: zohurulislam.engg @ gmail.com
}

Received: 5 April 2012

Accepted: 15 November 2012

\begin{abstract}
The consumer demand is increasing for composite flour based bakery products like biscuits. The incorporation of brown rice flour can be justified in composite flour based biscuits as it has beneficial nutraceutical properties and its gluten-free nature can play important role in preventing celiac problem. The physicochemical and functional properties of brown rice and wheat flour were studied and biscuits were prepared with the incorporation of brown rice flour in $0,5,10,15$ and $20 \%$ with the wheat flour to assess the quality and acceptability of the biscuits. The water absorption capacity of brown rice flour was lower than that of wheat flour ( $\mathrm{p} \leq 0.05)$, whereas oil absorption and foaming capacity of brown rice flour were significantly higher than that of wheat flour $(\mathrm{p} \leq 0.05)$. The brown rice flour had higher least gelation concentration (30.66\%) as compared with wheat flour (20.33\%). As the concentration of brown rice flour was increased, spread ratio of biscuits decreased. The biscuits containing 5, 10 and $15 \%$ brown rice flour indicated that addition of increasing level of brown rice flour had higher ash, fat, moisture and crude fiber contents, while protein and total carbohydrate contents found lower in the biscuits. Statistical analysis of biscuits containing various amount of brown rice flour $(0,5,10,15$ and $20 \%$ brown rice flour) showed that control biscuits ( $0 \%$ brown rice flour) secured the highest score for color, flavor, texture and overall acceptability, which is followed by biscuits containing $10,5,15$ and $20 \%$ brown rice flour.
\end{abstract}

Keyword: Brown rice flour (BRF), functional properties, physiochemical properties, supplemented biscuits, sensory quality

\section{Introduction}

Brown rice is the entire grain with only the inedible outer husk removed. Brown rice flour can be added in to the baked products due to different flavor and texture. Several methods exist for stabilizing rice bran separated during the raw milled rice (Sayre et al., 1982). In some parboiling systems, lipase activity is sufficiently inactivated to stabilize the bran. The rice bran has higher ash content than other cereal bran. The bran rice contains $12-16 \%$ protein which has high nutritional value. The addition of rice bran improves the lysine content of baked product and also contributes a blend pleasant flavor (Lynn, 1969). However the starchy endosperm is cooked in the process. Parboiling and other pretreatment processes are the suitable sources of 
producing modified rice flours, which are importance in preparing formulated baked products. If the pre treatment includes gelatinization of starch, use of the flour in the fermented baked products is limited, due to its high water uptake during the dough mixing stage. The increased water causes unpredictable changes in dough properties during fermentation. Rice flour offers potential for new and traditional baked products. It can be produced with a wide assortment of functional properties and factors affecting that properties are the varieties and types used milling and grinding methods employed, and pretreatment of rice or flour before use. Certain inherent properties have been identified as providing the most suitable flours for traditional products or as substitutes for wheat flour in breads and cakes. The low quality of protein in rice is offset to some degree by its high quality relative to that of other common cereals (Juliano and Bechtel, 1985).

Food processing industries are in developing stage in Bangladesh and consumption of processed baked products is gradually becoming popular. Composite flour biscuit is the most widely used bake product items in urban and sub-urban areas in Bangladesh. As a result of changing food habits, increasing population and urbanization the consumption of leavened wheat baked product has risen dramatically in many developed countries including Bangladesh. On the other hand for climatic reason many developing countries can not grow wheat suitable for baked product manufacturing. Thus partial substitutions of wheat flour with flour from indigenous crops or the production of alternative wheat less biscuits may be the subject of research. The major objectives of the study are (i) to compare the physicochemical and functional properties of brown rice flour (BRF) and wheat flour (WF); (ii) to prepare biscuits with the incorporation of brown rice flour in to the various proportions of wheat flour and (iii) to assess the quality and acceptability of prepared biscuits.

\section{Materials and Methods}

The experiment was conducted in the laboratory of the Department of Food Technology and Rural Industries, Bangladesh Agricultural University, Mymensingh, 2009-2010.

\subsection{Materials}

The raw paddy pajam (Oryza sativa) sample was collected from local market. Then the sample was dried to a desirable level moisture content of $12 \%$ and dehusking was done with the help of the Crushing Rolling machine. After dehusking, the brown rice flour was prepared by grinding brown rice kernel in flour mill with particle size of $0.12-0.150 \mu \mathrm{m}$. Other materials like refined wheat flour, sugar, fat etc. required for biscuit making were purchased from local market.

\subsection{Biscuit formulation}

The basic formulations used for preparation of biscuits are outlined in Table 1. The biscuits were prepared with the incorporation of brown rice flour (BRF) in 0, 5, 10, 15 and $20 \%$ concentration with wheat flour (WF). Brown rice flour, wheat flour and other ingredients were weighed accurately. The pre-weight ingredients were mixed properly. The baking chemicals and sugar were dissolved in water. Mixture of raw materials was added to obtain uniform dough and the dough was allowed to relax for 15 minutes before rolling out. The dough was then kneaded and rolled to a uniform thickness of 3 $\mathrm{mm}$. The rolled out dough was allowed to relax for 5 minutes. Then the biscuits were cut out with round biscuits cutter of $3.5 \mathrm{~cm}$ diameter. The cut out biscuits were placed on a greased or paper lined pans about 0.5 inch apart and the biscuit were allowed to rest on the pan about 10 minutes and baked at $220{ }^{\circ} \mathrm{C}$ for $10-15$ minutes, cooled to ambient temperature and packed in high density polyethylene bags. 
Table 1. Basic formulation of biscuits

\begin{tabular}{lccccc}
\hline & \multicolumn{5}{c}{ Biscuit Formulation } \\
\cline { 2 - 6 } Ingredients & $\mathrm{A}$ & $\mathrm{B}$ & $\mathrm{C}$ & $\mathrm{D}$ & $\mathrm{E}$ \\
\hline Wheat flour $(\mathrm{g})$ & 100 & 95 & 90 & 85 & 80 \\
Brown rice flour $(\mathrm{g})$ & 0 & 5 & 10 & 15 & 20 \\
Sugar $(\mathrm{g})$ & 40 & 40 & 40 & 40 & 40 \\
Fat (g) & 35 & 35 & 35 & 35 & 35 \\
Salt (g) & 0.5 & 0.5 & 0.5 & 0.5 & 0.5 \\
Milk powder $(\mathrm{g})$ & 2 & 2 & 2 & 2 & 2 \\
Water (ml) & 15 & 15 & 15 & 15 & 15 \\
Ammonium & 1.5 & 1.5 & 1.5 & 1.5 & 1.5 \\
bicarbonate $(\mathrm{g})$ & & &
\end{tabular}

\subsection{Proximate composition}

The functionality of flours of cereals grains, which depends to a great extent upon starch and protein content of flours, contribute a lot to the formulation and properties of the final product Therefore, flours were analyzed for their physicochemical and functional properties. Particularly, the functional properties are required for the formulation of value added composite bakery products.

\subsubsection{Physicochemical properties}

Protein (micro- Kjeldahl, x 6.25), fat (solvent extraction), moisture, ash and crude fiber were determined by the AOAC (2004) methods. The carbohydrate content was calculated by subtraction method.

\subsubsection{Functional properties}

Water and oil absorption capacity: The water and oil absorption capacities were determined by the method of Sosulski et al., 1986. The sample $(1.0 \mathrm{~g})$ was mixed with $10 \mathrm{ml}$ distilled water or refined soybean oil, kept at ambient temperature for $30 \mathrm{~min}$ and centrifuged for $10 \mathrm{~min}$ at $2000 \times \mathrm{g}$. Water or oil absorption capacity was expressed as percent water or oil bound per gram of the sample.
Bulk density: The bulk density was determined according to the method described by Okaka and Potter (1977). The sample (50 g) was put into a $100 \mathrm{ml}$ graduated cylinder and tapped 20-30 times. The bulk density was calculated as weight per unit volume of sample.

Least gelation concentration: The least gelation concentration was determined using method of Coffman and Garcia (1977) with some modifications. The flour dispersions of 2, 4, 6, 8, $10,12,14,16,18$ and $20 \%$ (w/v) prepared in 5 $\mathrm{ml}$ distilled water was heated at $90^{\circ} \mathrm{C}$ for $1 \mathrm{~h}$ in a water bath. The contents were cooled under tap water and kept for $2 \mathrm{~h}$ at $10 \pm 2^{\circ} \mathrm{C}$. The least gelation concentration was determined as that concentration when the sample from inverted tube did not slip.

Swelling capacity: The method of Okaka and Potter (1977) with some modifications was used for determining the swelling capacity. The sample filled up to $10 \mathrm{ml}$ mark in a $100 \mathrm{ml}$ graduated cylinder was added with water to adjust total volume to $50 \mathrm{ml}$. The top of the graduated cylinder was tightly covered and mixed by inverting the cylinder. The suspension was inverted again after $2 \mathrm{~min}$ and allowed to stand for further $30 \mathrm{~min}$. The volume occupied by the sample was taken after $30 \mathrm{~min}$. 
Foaming capacity and foaming stability: Foaming capacity and foaming stability were determined as described by Narayana and Narasinga Rao (1982) with slight modifications. Sample (1.0 g) was added to $50 \mathrm{ml}$ distilled water at $30 \pm 2^{0} \mathrm{C}$ in a graduated cylinder. The suspension was mixed and shaken for $5 \mathrm{~min}$ to foam. The volume of foam after whipping for 30 sec was expressed as foaming capacity. Where, AW: After whipping, BW: Before whipping, the volume of foam was recorded after 1hour whipping to determine foaming stability as percent of the initial foam volume.

\subsection{Physical analysis of biscuits}

Diameter of biscuits was measured by laying three biscuits edge to edge with the help of a scale rotating them $90^{\circ}$ and again measuring the diameter of three biscuits $(\mathrm{cm})$ and then taking average value. Thickness as measured by stacking three biscuits on top of each other and taking average thickness $(\mathrm{cm})$. Weight of biscuits was measured as average of values of three individual biscuits with the help of digital weighing balance. Spread ratio was calculated by dividing the average value of diameter by average value of thickness of biscuits. Percent spread was calculated by dividing the spread ratio of supplemented biscuits with spread ratio of control biscuits and multiplying by 100 .

\subsection{Sensory analysis of biscuits}

Biscuit samples were analyzed for sensory characteristics. Sensory quality characteristics were evaluated by a panel of 10 semi-trained members using a 9-point Hedonic scale where 9 $=$ like extremely; $8=$ like very much; $7=$ like moderately; 6 = like slightly; $5=$ neither like nor dislike; $4=$ dislike slightly; $3=$ dislike moderately; 2 = dislike very much; 1 = dislike extremely. The biscuits were evaluated for their color, appearance, flavor, texture, taste and overall acceptability.

\subsection{Statistical analysis}

Data was analyzed using analysis of variance. Duncan multiple range test was used to determine significant difference among the various samples in triplicate. Data were analyzed using the software, statistical package for social science (SPSS) version 11.00 SPSS inc., Chicago, IL, USA at the 0.05 level.

\section{Results and Discussion}

\subsection{Proximate composition of flours}

Table 2 shows that the functional properties of the flour samples. There was a significant difference amongst the samples $(\mathrm{P}<0.05)$. A significant difference was also observed in moisture, ash, crude fiber, carbohydrate and protein content of brown rice and refined wheat flour $(\mathrm{P} \leq 0.05)$. Brown rice flour showed lower protein content $(8.50 \%)$ and higher fat $(2.80 \%)$, ash $(1.77 \%)$, crude fiber $(1.23 \%)$ and carbohydrate content $(77.31 \%)$ in comparison to refined wheat flour. On the other hand wheat flour contained higher protein $(12.58 \%)$ and moisture content $(12.98 \%)$ than brown rice flour. The fat $(2.80 \%)$, ash $(1.77 \%)$ and carbohydrate content $(77.31 \%)$ of brown rice flour observed in this study is more or less similar but the crude fiber content was observed in higher value (Rosniyana et al., 2011).

\subsection{Functional properties of flours}

The functional properties of flours play important role in the manufacturing of bakery products. The brown rice flour (BRF) and refined wheat flour (WF) were analyzed for their functional properties. Table 3 shows the various functional properties of flours. The water absorption capacity (WAC) of brown rice flour was found to be significantly lower than that of wheat flour $(\mathrm{p} \leq 0.05)$. The oil absorption capacity (OAC) of brown rice flour was significantly higher than that of refined WF $(\mathrm{p} \leq 0.05)$. The oil absorption capacity (OAC) of flour is equally important as it improves the mouth feel and retains the flavor. The swelling capacities of BRF and refined WF were 16.04 and $16.98 \mathrm{ml}$, respectively. The foaming capacity of BRF was higher than that of refined WF. Foaming 
capacity is assumed to be dependent on the configuration of protein molecules. Flexible proteins have good foaming capacity but highly ordered globular molecule gives low foam ability (Graham et al., 1976). The foam expansion and foam stability have been correlated with waterdispersible nitrogen (Yasumatsu et al., 1972). Food ingredients with good foaming capacity and stability can be used in bakery products (Akubor et al., 2000). The emulsion activity did not differ significantly between the BRF and refined WF and the corresponding values were 0.45 and $0.44 \%(\mathrm{p} \leq 0.05)$. The bulk density of BRF was $0.85 \mathrm{~g} / \mathrm{ml}$, significantly higher $(\mathrm{p} \leq 0.05)$ than that of the refined WF $(0.68 \mathrm{~g} / \mathrm{ml})$. The BRF had higher least gelation concentration $(30.66 \%)$ as compared with refined WF $(20.33 \%)$. The variation in the gelling properties of flours was attributed to the relative ratio of protein, carbohydrates and lipids that made up the flours and interaction between such components (Sathe et al., 1982).

Table 2. Proximate composition of flours

\begin{tabular}{lcc}
\hline \multicolumn{1}{c}{ Parameter } & Brown rice flour & Refined wheat flour \\
\hline Moisture (\%) & $9.61 \pm 0.12^{\mathrm{b}}$ & $12.98 \pm 0.02^{\mathrm{a}}$ \\
Protein $(\%)$ & $8.50 \pm 0.14^{\mathrm{b}}$ & $12.58 \pm 0.90^{\mathrm{a}}$ \\
Fat $(\%)$ & $2.80 \pm 0.03^{\mathrm{a}}$ & $1.80 \pm 0.01^{\mathrm{b}}$ \\
Ash $(\%)$ & $1.77 \pm 0.04^{\mathrm{a}}$ & $1.40 \pm 0.01^{\mathrm{b}}$ \\
Fiber $(\%)$ & $1.23 \pm 0.05^{\mathrm{a}}$ & $0.85 \pm 0.01^{\mathrm{b}}$ \\
${ }^{*}$ Carbohydrate $(\%)$ & 77.31 & 71.23 \\
\hline
\end{tabular}

The values are mean \pm S.D of three independent determinations. The means with different superscripts in a row differ significantly $(\mathrm{p} \leq 0.05) .{ }^{*}$ Calculated by difference method.

Table 3. Functional properties of flours

\begin{tabular}{lcc}
\hline \multicolumn{1}{c}{ Property } & Brown rice flour & Refined wheat flour \\
\hline Water absorption capacity \% & $125.38 \pm 0.10^{\mathrm{b}}$ & $145.97 \pm 0.08^{\mathrm{b}}$ \\
Oil absorption capacity \% & $196.25 \pm 0.03^{\mathrm{a}}$ & $161.19 \pm 0.98^{\mathrm{b}}$ \\
Swelling capacity $(\mathrm{ml})$ & $16.04 \pm 0.12^{\mathrm{b}}$ & $16.98 \pm 0.02^{\mathrm{a}}$ \\
Foaming capacity \% & $16.09 \pm 0.11^{\mathrm{a}}$ & $12.21 \pm 0.04^{\mathrm{a}}$ \\
Foaming stability \% & $86.45 \pm 0.52^{\mathrm{b}}$ & $97.16 \pm 0.16^{\mathrm{a}}$ \\
Emulsion activity \% & $0.45 \pm 0.00^{\mathrm{a}}$ & $0.44 \pm 0.01^{\mathrm{a}}$ \\
Bulk density (g/ml) & $0.85 \pm 0.01^{\mathrm{a}}$ & $0.68 \pm 0.00^{\mathrm{b}}$ \\
Least gelation concentration $\%$ & $30.66 \pm 0.57^{\mathrm{a}}$ & $20.33 \pm 0.57^{\mathrm{b}}$
\end{tabular}

The values are mean \pm S.D of three independent determinations. The means with different superscripts in a row differ significantly $(\mathrm{p} \leq 0.05)$. 


\subsection{Proximate composition of biscuits}

The proximate composition of biscuits is shown in Table 4. The ash content of biscuits increased with the addition of BRF. The increase in ash content may be due to the high dietary fiber and mineral content in the BRF i.e. iron, calcium, phosphorus and magnesium (Rosniyana et al., 2011). The moisture content ranged from 3.27 (20\% BRF) to $4.40 \%$ (control). The decrease in moisture content may be due to the decrease in protein content an increase in moisture content of bakery products with increase in protein content. The fat content of control biscuits was $21.21 \%$ and it increased to $23.47 \%$ in $20 \%$ BRF biscuits. Higher oil retention improves the mouth feel and retains the flavor of the biscuits. Similarly the fiber content of control biscuits was $0.97 \%$ and it increased to $1.84 \%$ in $20 \%$ BRF biscuits. This is due to the higher fiber content in brown rice flour. The protein content of biscuits ranged from 7.87 (20\% BRF to $9.37 \%$ (control). The biscuits showed decrease in protein content when BRF concentration was increased. The carbohydrate content as determined by difference method was found to be higher in control biscuits. The moisture, ash, protein, fat and total carbohydrate contents of biscuits were more or less similar to those reported by (Kabirullah et al., 1995).

\subsection{Physical properties of biscuits}

The physical properties of biscuits prepared from BRF and refined WF are shown in Table 5. The diameter of biscuits made from 10, 15 and $20 \%$ BRF was found significantly lower than that of control biscuit and biscuit from 5\% BRF ( $p$ $\leq 0.05$ ). The thickness of biscuits ranged from 0.53 to $0.63 \mathrm{~cm}$. It increased with the incorporation of BRF. Increase in thickness may be due to the decrease in diameter. The changes in diameter and thickness were reflected in spread ratio and percent spread of biscuit. The spread ratio and percent spread of control biscuits were 7.35 and 100, respectively. Spread ratio and percent spread decreased with the addition of brown rice flour. Other researchers also reported reduction in spread ratio when soy flour and fenugreek flour were substituted for wheat flour (Singh et al., 1996 and Hooda and Jood, 2005). Reduced spread ratios of BRF fortified biscuits were attributed to the fact that composite flours apparently formed aggregates with increased numbers of hydrophilic sites available that competed for the limited free water in biscuit dough (McWatters, 1978). The weight of biscuits increased as the concentration of BRF increased in the blends. The range of biscuit weight was 4.52 to $4.69 \mathrm{~g}$ with maximum value in $20 \%$ BRF biscuits.

Table 4. Chemical composition of biscuits

\begin{tabular}{lccccc}
\hline \multirow{2}{*}{ Parameter } & \multicolumn{5}{c}{ Biscuits types } \\
\cline { 2 - 6 } & $\mathrm{A}$ & $\mathrm{B}$ & $\mathrm{C}$ & $\mathrm{D}$ & $\mathrm{E}$ \\
\hline Moisture \% & $4.40 \pm 0.01^{\mathrm{a}}$ & $3.89 \pm 0.01^{\mathrm{b}}$ & $3.78 \pm 0.00^{\mathrm{c}}$ & $3.39 \pm 0.01^{\mathrm{d}}$ & $3.27 \pm 0.01^{\mathrm{e}}$ \\
Protein \% & $9.37 \pm 0.01^{\mathrm{a}}$ & $8.85 \pm 0.00^{\mathrm{b}}$ & $8.47 \pm 0.02^{\mathrm{c}}$ & $8.08 \pm 0.01^{\mathrm{d}}$ & $7.87 \pm 0.01^{\mathrm{e}}$ \\
Fat \% & $21.21 \pm .01^{\mathrm{a}}$ & $22.37 \pm 0.23^{\mathrm{b}}$ & $23.08 \pm 0.01^{\mathrm{c}}$ & $23.27 \pm 0.01^{\mathrm{d}}$ & $23.47 \pm 0.01^{\mathrm{e}}$ \\
Ash \% & $0.60 \pm 0.00^{\mathrm{e}}$ & $0.97 \pm 0.01^{\mathrm{d}}$ & $1.08 \pm 0.01^{\mathrm{c}}$ & $1.18 \pm 0.01^{\mathrm{b}}$ & $1.24 \pm 0.01^{\mathrm{a}}$ \\
Crude fiber \% & $0.97 \pm 0.00^{\mathrm{e}}$ & $1.39 \pm 0.00^{\mathrm{d}}$ & $1.68 \pm 0.01^{\mathrm{c}}$ & $1.78 \pm 0.01^{\mathrm{b}}$ & $1.84 \pm 0.01^{\mathrm{a}}$ \\
$*$ Carbohydrate \% & 64.41 & 63.91 & 63.57 & 64.10 & 64.13 \\
\hline
\end{tabular}

$\mathrm{A}=0 \% \mathrm{BRF}$ (Control); $\mathrm{B}=5 \% \mathrm{BRF} ; \mathrm{C}=10 \% \mathrm{BRF} ; \mathrm{D}=15 \% \mathrm{BRF} ; \mathrm{E}=20 \% \mathrm{BRF}$. The values are mean \pm S.D of three independent determinations. The means with different superscripts in a row differ significantly $(\mathrm{p} \leq 0.05)$. *Calculated by difference method. 
Table 5. Physical properties of biscuits

\begin{tabular}{lccccc}
\hline \multirow{2}{*}{ Parameter } & \multicolumn{5}{c}{ Biscuit types } \\
\cline { 2 - 6 } & $\mathrm{A}$ & $\mathrm{B}$ & $\mathrm{C}$ & $\mathrm{D}$ & $\mathrm{E}$ \\
\hline Diameter & $3.90 \pm 0.01^{\mathrm{a}}$ & $3.90 \pm 0.01^{\mathrm{a}}$ & $3.83 \pm 0.01^{\mathrm{b}}$ & $3.78 \pm 0.00^{\mathrm{c}}$ & $3.70 \pm 0.00^{\mathrm{d}}$ \\
Thickness & $0.53 \pm 0.00^{\mathrm{d}}$ & $0.54 \pm 0.01^{\mathrm{d}}$ & $0.57 \pm 0.00^{\mathrm{c}}$ & $0.58 \pm 0.01^{\mathrm{b}}$ & $0.63 \pm 0.00^{\mathrm{a}}$ \\
Spread ratio & $7.35 \pm 0.02^{\mathrm{a}}$ & $7.22 \pm 0.01^{\mathrm{a}}$ & $6.71 \pm 0.01^{\mathrm{b}}$ & $6.51 \pm 0.01^{\mathrm{c}}$ & $5.84 \pm 0.04^{\mathrm{d}}$ \\
Weight & $4.52 \pm 0.02^{\mathrm{d}}$ & $4.51 \pm 0.01^{\mathrm{d}}$ & $4.55 \pm 0.01^{\mathrm{c}}$ & $4.60 \pm 0.00^{\mathrm{b}}$ & $4.69 \pm 0.01^{\mathrm{a}}$ \\
\% Spread & 100 & 98.26 & 92.67 & 89.92 & 80.66 \\
\hline
\end{tabular}

$\mathrm{A}=0 \% \mathrm{BRF}$ (Control); B = 5\% BRF; C = 10\% BRF; D = 15\% BRF; E = 20\% BRF. The values are mean \pm S.D of three independent determinations. The means with different superscripts in a row differ significantly $(\mathrm{p} \leq 0.05)$.

Table 6. Mean sensory scores of formulated biscuits

\begin{tabular}{|c|c|c|c|c|c|c|}
\hline Parameter & $\begin{array}{l}\text { Biscuit } \\
\text { types }\end{array}$ & $\begin{array}{c}\text { Original order of } \\
\text { mean }\end{array}$ & $\begin{array}{l}\text { Biscuit } \\
\text { types }\end{array}$ & $\begin{array}{c}\text { Ranked order of } \\
\text { mean }\end{array}$ & LSD & $\begin{array}{c}\mathrm{P} \\
\text { value }\end{array}$ \\
\hline \multirow{5}{*}{ Colour } & A & $8.813^{\mathrm{a}}$ & A & $8.813^{\mathrm{a}}$ & \multirow{5}{*}{0.2873} & \multirow{5}{*}{0.05} \\
\hline & B & $7.938^{\mathrm{b}}$ & $\mathrm{C}$ & $8.563^{\mathrm{a}}$ & & \\
\hline & $\mathrm{C}$ & $8.563^{\mathrm{a}}$ & B & $7.938^{\mathrm{b}}$ & & \\
\hline & $\mathrm{D}$ & $7.188^{c}$ & $\mathrm{D}$ & $7.188^{\mathrm{c}}$ & & \\
\hline & $\mathrm{E}$ & $7.063^{\mathrm{c}}$ & $\mathrm{E}$ & $7.063^{\mathrm{c}}$ & & \\
\hline \multirow{5}{*}{ Flavour } & $\mathrm{A}$ & $8.688^{a}$ & $\mathrm{~A}$ & $8.688^{\mathrm{a}}$ & \multirow{5}{*}{0.3171} & \multirow{5}{*}{0.05} \\
\hline & B & $7.563^{\mathrm{b}}$ & B & $7.563^{\mathrm{b}}$ & & \\
\hline & $\mathrm{C}$ & $7.940^{\mathrm{b}}$ & $\mathrm{C}$ & $7.940^{\mathrm{b}}$ & & \\
\hline & $\mathrm{D}$ & $6.438^{c}$ & $\mathrm{D}$ & $6.438^{\mathrm{c}}$ & & \\
\hline & $\mathrm{E}$ & $5.875^{\mathrm{d}}$ & $\mathrm{E}$ & $5.875^{\mathrm{d}}$ & & \\
\hline \multirow{5}{*}{ Texture } & A & $8.250^{\mathrm{a}}$ & A & $8.250^{\mathrm{a}}$ & \multirow{5}{*}{0.5386} & \multirow{5}{*}{0.05} \\
\hline & B & $7.188^{\mathrm{b}}$ & $\mathrm{C}$ & $7.687^{\mathrm{b}}$ & & \\
\hline & $\mathrm{C}$ & $7.687^{\mathrm{b}}$ & B & $7.188^{\mathrm{b}}$ & & \\
\hline & $\mathrm{D}$ & $6.375^{\mathrm{c}}$ & $\mathrm{D}$ & $6.375^{\mathrm{c}}$ & & \\
\hline & $\mathrm{E}$ & $6.188^{\mathrm{c}}$ & $\mathrm{E}$ & $6.188^{\mathrm{c}}$ & & \\
\hline \multirow{5}{*}{$\begin{array}{c}\text { Overall } \\
\text { acceptability }\end{array}$} & A & $8.813^{\mathrm{a}}$ & A & $8.813^{\mathrm{a}}$ & \multirow{5}{*}{0.3317} & \multirow{5}{*}{0.05} \\
\hline & B & $7.875^{\mathrm{b}}$ & $\mathrm{C}$ & $7.875^{\mathrm{b}}$ & & \\
\hline & $\mathrm{C}$ & $8.500^{\mathrm{a}}$ & B & $8.500^{\mathrm{a}}$ & & \\
\hline & $\mathrm{D}$ & $6.750^{c}$ & $\mathrm{D}$ & $6.750^{\mathrm{c}}$ & & \\
\hline & $\mathrm{E}$ & $6.438^{c}$ & $\mathrm{E}$ & $6.438^{\mathrm{c}}$ & & \\
\hline
\end{tabular}

$\mathrm{A}=0 \% \mathrm{BRF}$ (Control); $\mathrm{B}=5 \% \mathrm{BRF} ; \mathrm{C}=10 \% \mathrm{BRF} ; \mathrm{D}=15 \% \mathrm{BRF} ; \mathrm{E}=20 \% \mathrm{BRF}$. The means with different superscripts in a column differ significantly $(\mathrm{p} \leq 0.05)$. 


\subsection{Sensory characteristics of biscuits}

The sensory characteristics of biscuits prepared from BRF and refined WF are shown in Table 6. The analysis indicated that there were significant differences in flavor, texture, overall acceptability between control biscuits and biscuits containing brown rice flour $(\mathrm{p} \leq 0.05)$. With the increase in the level of BRF in the formulation, the sensory scores for color, texture, appearance and flavor of biscuits decreased. The color and overall acceptability scores of control biscuits and biscuits with $10 \%$ brown rice flour were statistically similar. The score of texture reduced from 8.250 to 6.188 at $20 \%$ concentration of BRF. This was because of cracks formed with the addition of gluten free BRF. The use of non-glutenous composite flours in cookie preparation reduces the textural strength of cookies where such strength is dependent upon approximate levels of gluten development. This is because in contrast to bread, the gluten network in cookies is to be only slightly cohesive without being too elastic (Schober et al. 2003). The score of flavour reduced significantly 8.688 (control) from 5.875 at $20 \%$ BRF. The biscuits formed with addition of BWF got overall acceptability score of 8.813 (control) to 6.438 (20\% BRF).

\section{Conclusions}

The present study concluded that brown rice flour can be successfully incorporated in refined wheat flour biscuits up to a level of $10 \%$ to yield biscuits of enhanced nutritional quality with acceptable sensory attributes. Hence, development and utilization of such functional foods will not only improve the nutritional status of the population but also helps those suffering from degenerative diseases. The finding of this experiment may help generate technology to diversify the use of brown rice flour by the food processing enterprises, specially baking industries. More studies should be conducted to investigate the possibility of using $\mathrm{BRF}$ as an ingredient in other food products in order to increase applications of such value-added food ingredient.

\section{Acknowledgements}

The authors gratefully acknowledge to the Department of Food Technology and Rural Industries, Bangladesh Agricultural University, Mymensingh, Bangladesh for providing the facilities to carry out this research work.

\section{References}

Akubor, P. I., Isolokwu, P.C., Ugbane, O. and Onimawo, I. A. 2000. Proximate composition and functional properties of African breadfruit kernel and wheat flour blends. Food Research International, 33: 707-712.

AOAC. 2004. Official method of Analysis of the Association of official Analytical chemists. $15^{\text {th }}$ Ed., Washington. USA.

Coffmann, C. W. and Garcia, V. V. 1977. Functional properties and amino acid content of a protein isolate from mung bean flour. Journal of Food Technology, 12:473-480.

Graham, D. E. and Philips, M. C. 1976. The A.Rosniyana conformation of proteins at the air-water interface and their role in stabilizing foam. In Akers, R.J. (Ed.). FoamsNew York: Academic Press, 237$255 \mathrm{pp}$.

Hooda, S. and Jood, S. 2005. Organoleptic and nutritional evaluation of wheat biscuits supplemented with untreated and treated fenugreek flour. Food Chemistry, 90: 427435.

Juliano B. O. and Bechtel, D. B. 1985. The grain and its gross composition. In : Rice Chemistry and Technology, Los Banos, Laguna : IRRI, 17-57 pp.

Kabirullah, M., Rukonuddin. A., Khan, S. A., Mosharef, H., Mojibur, R. A., K. M. Azizul M. I. K. and Moazzam, M. H. 1995. Analysis of Nutrients of Bangladeshi Processed Foods. Part IDifferent types of biscuits. Bangladesh 
Journal of Scientific and Industrial Research, 30 (1): 121.

Lynn, J. 1969. Edible rice bran Food. In protein enriched cereal Foods for world needs. M. Milner (Editor). American Association Cereal Chemistry St. Paul, Minn, 154-172 pp.

McWatters, K. M. 1978. Cookie baking properties of defatted peanut, soybean and field pea flours in baking powder biscuits. Cereal Chemistry, 55: 853-863.

Mustafa A. I., Alwessali, M. S., SI-Busha, O. M. and AI- Amia, R. H. 1986. Utilization of cowpea flour and protein isolate in bakery products. Cereal Food World, 31: 756-59.

Narayana, K. and Narasinga Rao, M. S. 1982. Functional properties of raw and heat processed winged bean flour. Journal of Food Science, 42: 534-538.

Okaka, J. C. and Potter, N. N. 1977. Functional and storage properties of cowpea-wheat flour blends in bread making. Journal of Food Science, 42: 828-833.

Rosniyana, A., Sarmin, S. and Shariffah, N. 2011. Quality Evaluation of Brown Rice Flour Made From Malaysian Rice Variety. The 12th Asean Food Conference, 16-18 June, 2011, BITEC Bangna, Bangkok, Thailand, $782 \mathrm{p}$.
Sathe, S. K., Deshpande, S. S. and Salunkhe, D. K. 1982. Functional properties of winged bean proteins. Journal of Food Science, 47: 503-508.

Sayre, R. N., Saunders, R. M., Enochian, R. V., Schultz,W. G. and Beagle, E. C.1982. Review of rice bran stabilization systems with emphasis on extrusion cooking. Cereal foods world, 27:317-322.

Schober, T. J., Brien, C. M. McCarthy, D., Barnedde, A. and Arendt, E. K. 2003. Influence of gluten free flour mixes and fat powders in the quality of gluten free biscuits. European Food Research Technology, 5: 369-376.

Singh, R., Singh, G. and Chauhan, G. S. 1996. Effect of incorporation of defatted soya flour on the quality of biscuits. Journal of Food Science and Technology, 33:355357.

Sosulski, F. W., Garratt. M. O. and Slinkard, A. E. 1976. Functional properties of ten legume flours. International Journal of Food Science and Technology, 9: 66-69.

Yasumatsu, K., Sawada, K. Maritaka, S., Mikasi, M., Toda, J., Wada. T. and Ishi, K. 1972. Whipping and emulsifying properties of soybean products. Agricultural and Biological Chemistry, 36: 719-727. 